\title{
Flavonoid Analyses and Antimicrobial Activity of Various Parts of Phaleria macrocarpa (Scheff.) Boerl Fruit
}

\author{
Rudi Hendra ${ }^{1,2}$, Syahida Ahmad ${ }^{1, *}$, Aspollah Sukari ${ }^{3}$, M. Yunus Shukor ${ }^{1}$ and \\ Ehsan Oskoueian ${ }^{4}$
}

1 Department of Biochemistry, Faculty of Biotechnology and Biomolecular Sciences, Universiti Putra Malaysia (UPM), 43400 UPM Serdang, Selangor, Malaysia;

E-Mails: rootdee2001@ yahoo.com (R.H.); yunus@ biotech.upm.edu.my (M.Y.S.)

2 Department of Chemistry, Faculty of Mathematic and Natural Sciences, University of Riau, Pekanbaru, Riau, Indonesia

3 Department of Chemistry, Faculty of Sciences, Universiti Putra Malaysia (UPM), 43400 UPM Serdang, Selangor, Malaysia; E-Mail: aspollah@science.upm.edu.my

4 Department of Microbiology, Faculty of Biotechnology and Biomolecular Sciences, Universiti Putra Malaysia (UPM), 43400 UPM Serdang, Selangor, Malaysia; E-Mail: ehs424@yahoo.com

* Author to whom correspondence should be addressed; E-Mail: syahida@ biotech.upm.edu.my; Tel.: +603-89466694; Fax: +603-89430913.

Received: 21 March 2011; in revised form: 6 April 2011 / Accepted: 10 May 2011 / Published: 27 May 2011

\begin{abstract}
Phaleria macrocarpa (Scheff.) Boerl (Thymelaceae) is commonly known as 'Crown of God', 'Mahkota Dewa', and 'Pau'. It originates from Papua Island, Indonesia and it grows in tropical areas. Empirically, it is potent in treating the hypertensive,diabetic, cancer and diuretic patients. It has a long history of ethnopharmacological usage, and the lack of information about its biological activities led us to investigate the possible biological activities by characterisation of flavonoids and antimicrobial activity of various part of $P$. macrocarpa against pathogenic bacteria and fungi. The results showed that kaempferol, myricetin, naringin, and rutin were the major flavonoids present in the pericarp while naringin and quercetin were found in the mesocarp and seed. Furthermore, the antibacterial activity of different parts of P. macrocarpa fruit showed a weak ability to moderate antibacterial activity against pathogenic tested bacteria (inhibition range: $0.93-2.17 \mathrm{~cm}$ ) at concentration of $0.3 \mathrm{mg} /$ disc. The anti fungi activity was only found in seed extract against Aspergillus niger $(1.87 \mathrm{~cm})$ at concentration of $0.3 \mathrm{mg} /$ well. From the
\end{abstract}


results obtained, $P$. macrocarpa fruit could be considered as a natural antimicrobial source due to the presence of flavonoid compounds.

Keywords: $P$. macrocarpa; flavonoid; antimicrobial activity

\section{Introduction}

Phaleria macrocarpa (Scheff.) Boerl (Thymelaceae) is commonly known as 'Crown of God', 'Mahkota Dewa', and 'Pau'. It originates from Papua Island, Indonesia and it grows in tropical areas. This plant is one of the most popular medicinal plants in Indonesia. P. macrocarpa grows throughout the year in tropical areas reaching a height of around 1-6 m. It is a complete tree (stem, leaves, flower and fruit) and the fruits are eclipse-shaped with a diameter of around $3 \mathrm{~cm}$. The color of the fruit is green before ripening and red when fully ripe [1]. Previous studies on secondary metabolites from $P$. macrocarpa have confirmed the presence of Kaempferol-3-O- $\beta$-D-glucoside in the fruit and it was found to protect H4IIE rat hepatoma against oxidative stress [2,3]. In addition, Osimi [4] isolated 3 compounds (icariside $\mathrm{C}_{3}$, phalerin, and mangiferin) from the fruit and icariside $\mathrm{C}_{3}$ showed a slow vasorelaxant activity against noradrenaline-induced contraction of isolated rat aorta. Moreover, benzophenone glucoside and 4'-6'-dihyroxy-4-metoxybenzophenone-2-O-glucoside were isolated from the fruit and leaves [5,6].

Empirically, it is believed that it has the potential to treat hypertension, diabetes, cancer and diuretic conditions. Natural phytochemicals have been reported to possess a wide range of biological activities including antioxidant, antimicrobial and anti-inflammatory properties [7]. Recently, there has been a growing interest in the investigation and introduction of medicinal plants with various biological activities to the pharmaceutical industries since synthetic drugs have been associated with several side effects on human health. Furthermore, microorganisms indicated a resistance to synthetic antimicrobial agents, which is a serious and immediate concern [8,9]. Due to these facts, the exploration of new alternative medicines derived from plants is required. Flavonoids are classified under phenolic groups in plants which have been known to possess antimicrobial activity [10]. The mechanisms of flavonoids that are antimicrobial can be classified as the inhibition of nucleic acid synthesis, cytoplasmic membrane function, and energy metabolism [11]. There has been a long history of ethnopharmacological usage and the lack of information about $P$. macrocarpa fruit's biological activities led us to investigate the possible biological activities by the characterization of flavonoids and antimicrobial activity of various parts of this fruit against various pathogenic bacteria and fungi.

\section{Results and Discussion}

\subsection{Flavonoid Compounds Analyses}

Flavonoid compounds present in P. macrocarpa fruits were analyzed by using Reversed-Phase High Performance Liquid Chromatography (RP-HPLC). The flavonoid compounds have been identified according to their retention times and quantified according to their respective standard calibration curves (Figures 1, 2 and 3). Kaempferol, myricetin, naringin, and rutin were found as 
flavonoid compounds in pericarp of $P$. macrocarpa fruit (Table 1). The results also confirmed the presence of naringin and quercetin in mesocarp. Moreover, the seed of $P$. macrocarpa fruit contained only quercetin with the value of $0.452 \mathrm{mg} / \mathrm{g}$ dried weight (DW).

Figure 1. Flavonoids content of pericarp of P. macrocarpa analysed by HPLC at the wavelength of $365 \mathrm{~nm}$.

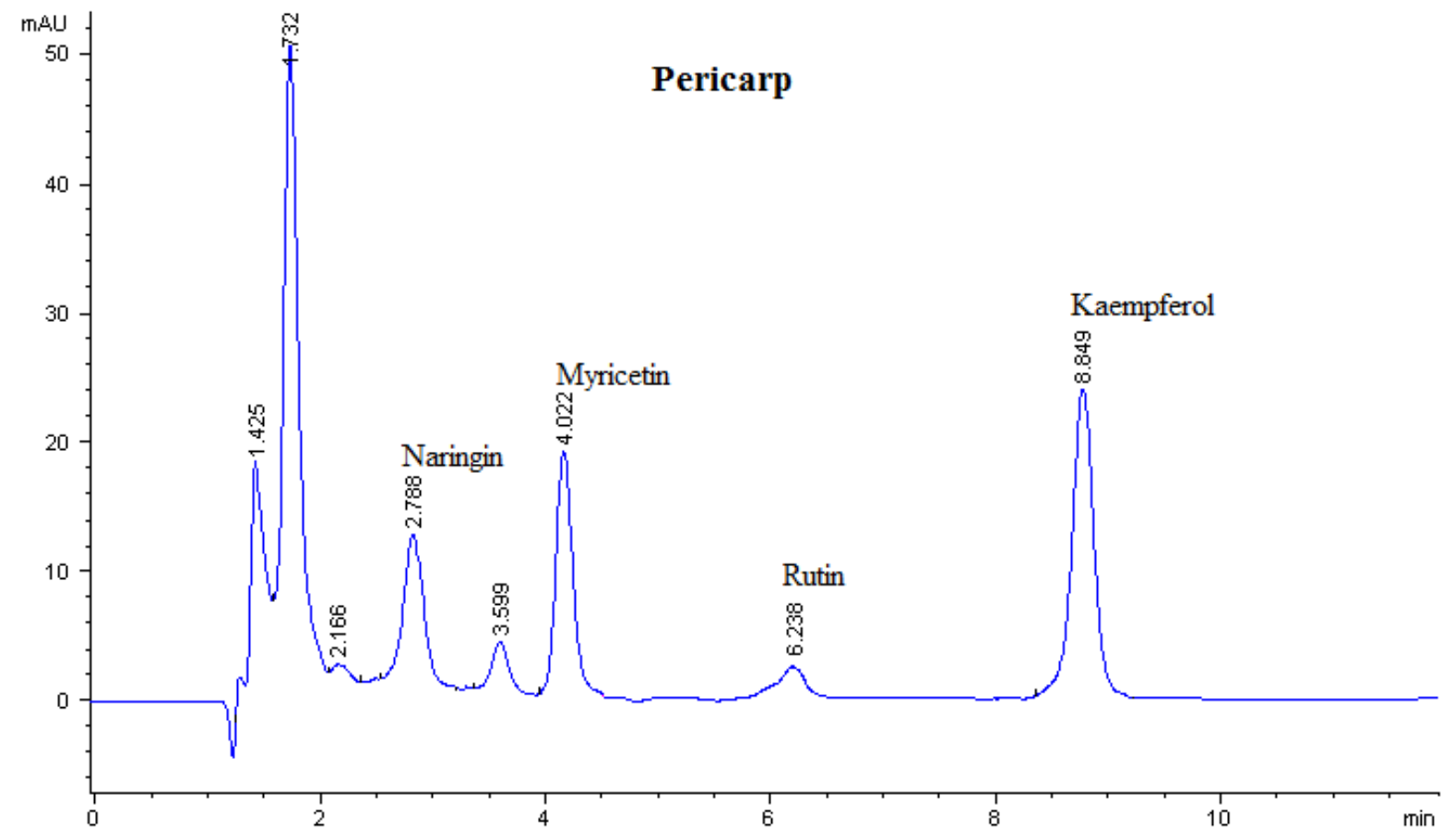

Figure 2. Flavonoids content of mesocarp of P. macrocarpa analysed by HPLC at the wavelength of $365 \mathrm{~nm}$.

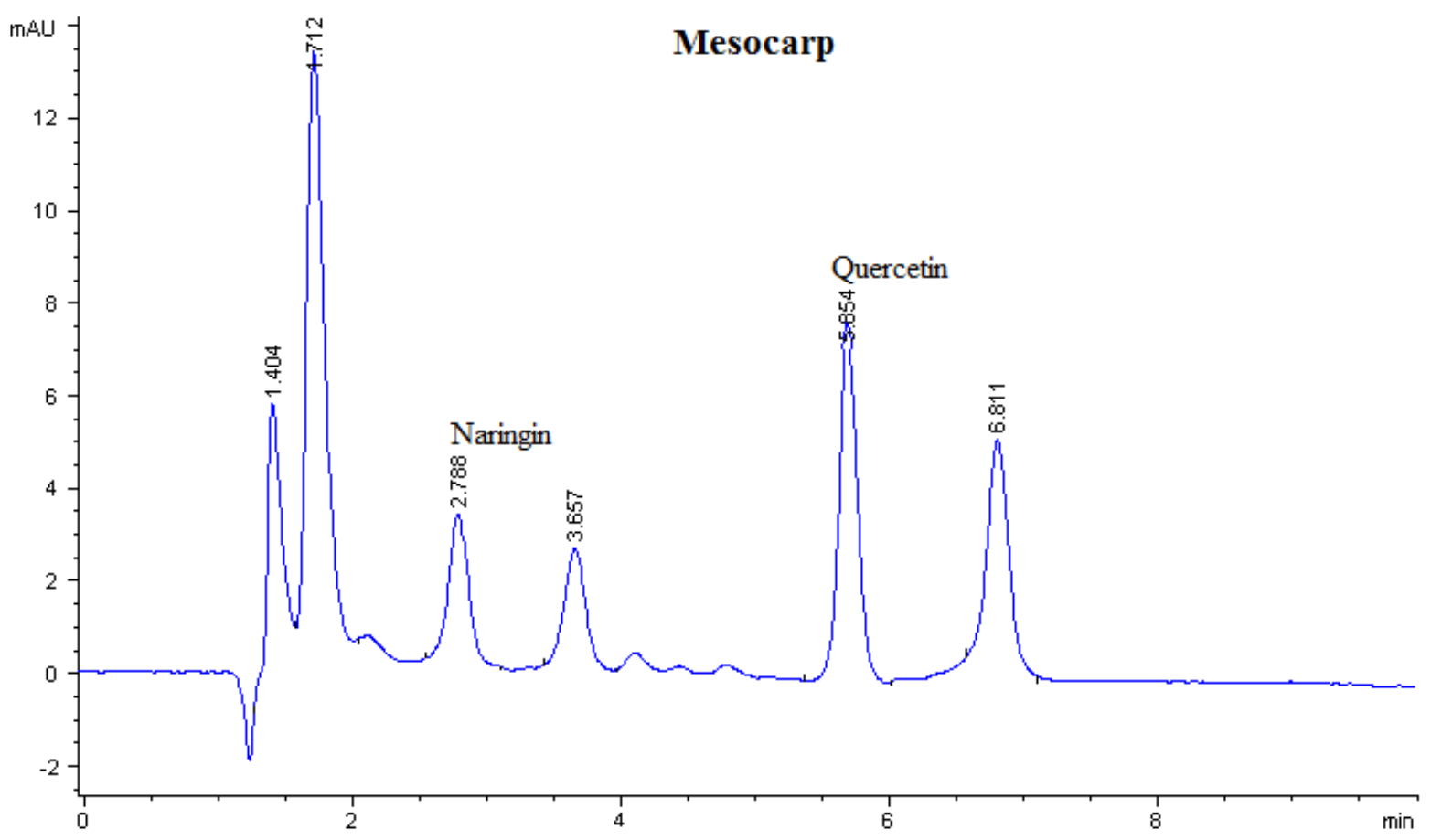


Figure 3. Flavonoids content of seed of $P$. macrocarpa analysed by HPLC at the wavelength of $365 \mathrm{~nm}$.

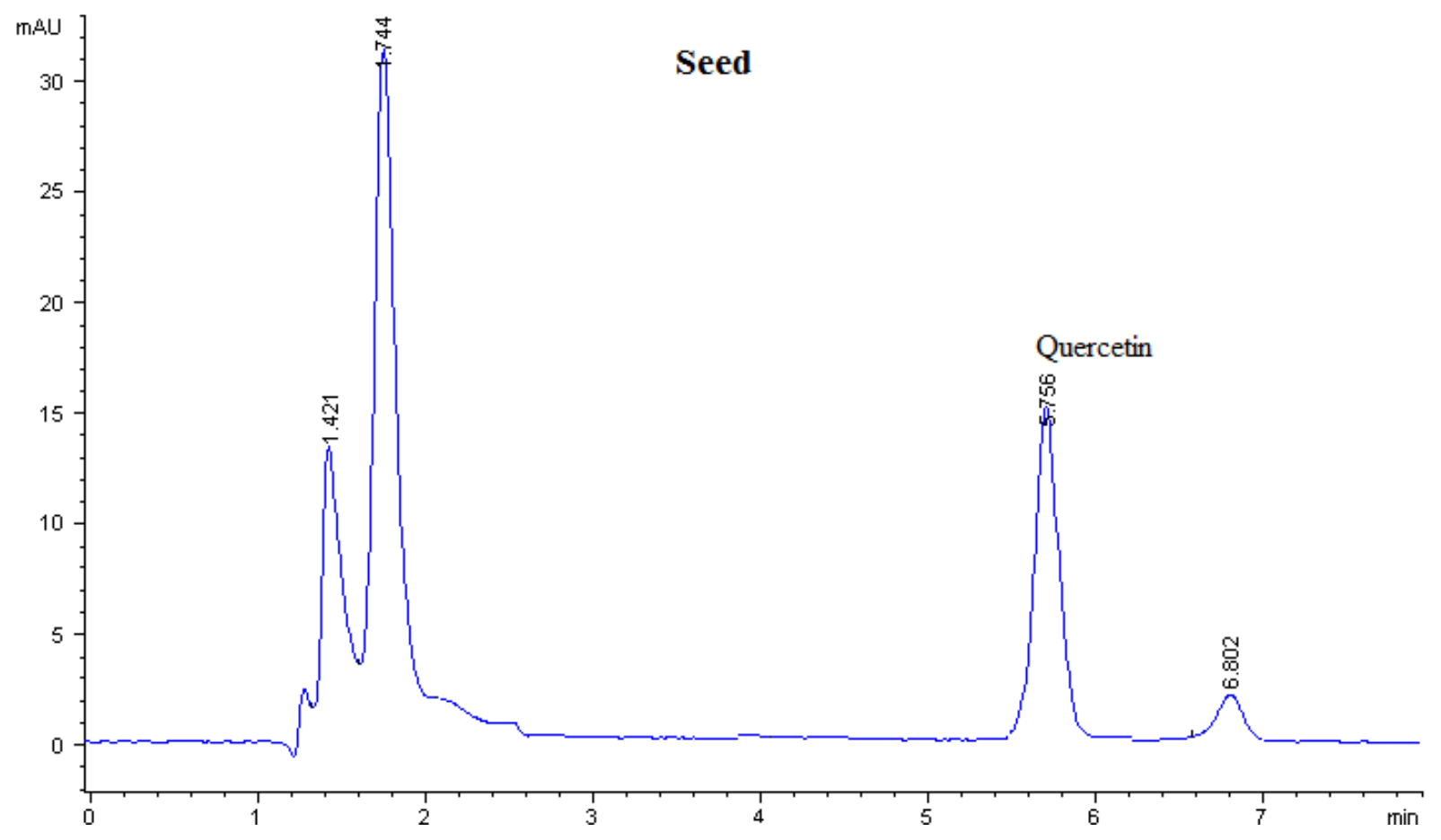

Table 1. Contents of flavonoids compounds in pericarp, mesocarp, and seed of $P$. macrocarpa fruit.

\begin{tabular}{cccccccc}
\hline \multirow{2}{*}{ Sample } & \multicolumn{7}{c}{ Flavonoid contents $(\boldsymbol{\mu g} / \mathbf{g}$ DW) } \\
\cline { 2 - 8 } & Apigenin & Kaempferol & Luteolin & Myricetin & Naringin & Quercetin & Rutin \\
\hline Pericarp & - & $76.00 \pm 0.003$ & - & $59.90 \pm 0.001$ & $39.80 \pm 0.001$ & - & $17.80 \pm 0.001$ \\
Mesocarp & - & - & - & - & 1.90 & $31.80 \pm 0.002$ & - \\
Seed & - & - & - & - & - & $45.20 \pm 0.003$ & - \\
\hline
\end{tabular}

-Not detected; analysis were done in triplicate.

Among the flavonoids detected, the kaempferol content was significantly $(\mathrm{p}<0.05)$ higher in the pericarp extract $(76 \mu \mathrm{g} / \mathrm{g} \mathrm{DW})$. This value was lower than the kaempferol value in Chinese tea leaves (1.56-3.31 mg/g dried leaves) [12] but higher than in strawberries (8 $\mu \mathrm{g} / \mathrm{g}$ dried-weight) [13]. This finding was supported by Zhang et al. [3] who isolated the kaempferol-3-O- $\beta$-D-glucoside from P. macrocarpa fruit.

Myricetin (59.90 $\mu \mathrm{g} / \mathrm{mg}$ DW) located at the pericarp has a lower content compared with blackcurrant (71 $\mu \mathrm{g} / \mathrm{mg}$ DW) but higher than blueberry (26 $\mu \mathrm{g} / \mathrm{mg}$ DW) [13]. The amount of naringin present at the pericarp and mesocarp (39.00 and $1.90 \mu \mathrm{g} / \mathrm{mg} \mathrm{DW})$ was found to be lower than that of citrus (3.26 mg/g DW) [14]. Furthermore, rutin was detected in pericarp with a value of $17.80 \mu \mathrm{g} / \mathrm{mg}$ DW and it was found to be lower than citrus with a value of $3.26 \mathrm{mg} / \mathrm{g}$ DW [14] and Amaranthus viridis (58.2 $\mu \mathrm{g} / \mathrm{mg} \mathrm{DW})$ [15]. Table 1 shows the concentration of quercetin present in mesocarp and seed with the values of 31.80 and $42.80 \mu \mathrm{g} / \mathrm{mg} \mathrm{DW}$, respectively. These values were found to be lower than the quercetin that is found in onion and garlic which is reported by Crozier et al. [16] with value 201 and $227 \mu \mathrm{g} / \mathrm{mg}$ DW. 


\subsection{Antimicrobial Activity}

The results obtained from antimicrobial assay are presented in Table 2 at a concentration of $0.3 \mathrm{mg} /$ disc. According to Table 2, the extracts of $P$. macrocarpa fruit showed variable ranges of antimicrobial activities against 8 bacteria (Gram-positive and Gram-negative).

In general, most of the extracts indicated weak to moderate inhibitory activities against the bacteria tested. The extract of $P$. macrocarpa fruits at $0.3 \mathrm{mg} / \mathrm{disc}$ showed variable inhibitory activity against all bacteria with inhibition zone diameters ranging from $0.93-2.33 \mathrm{~cm}$, as shown in Table 1 . The microorganisms responses were different to the different extracts obtain from various parts of $P$. macrocarpa friut. Pericarp of $P$. macrocarpa fruit showed high inhibition on Gram-positive and Gram-negative bacteria compared to mesocarp, seed and kanamycin ( $1 \mu \mathrm{g} / \mathrm{disc})$. In this study, it was shown that all the extracts could give higher inhibition to Gram-positive bacteria compared to Gram-negative bacteria. These results are in agreement with Othman [17] that Gram-negative microorganisms are typically more resistant to antimicrobial agents than Gram-positive bacteria. This has long been explained by the presence of an outer-membrane permeability barrier in Gram-negative bacteria, which limits access of the antimicrobial agents to their targets in the bacterial cells.

Furthermore, all the extracts assayed indicate no activity to weak inhibitory activities against all fungi. Based on Table 1, the antifungal activity of extracts from different parts, pericarp and mesocarp showed no antifungal activity against all fungi tested but seed extract at the concentration of $0.3 \mathrm{mg} /$ well showed antifungal activity against Aspergilus. niger with inhibition $1.87 \mathrm{~cm}$. This inhibition was low compared to Amphotericin B $(25 \mu \mathrm{g} / \mathrm{well})$. Interestingly, the tested bacteria and fungi showed different sensitivities to the different extracts of $P$. macrocarpa fruit. These results might be due to the presence of phytochemical in seeds such as phorbol esters. Borris et al. [18] mentioned that Phaleria sp. contain phorbol esters which are present in the seed of the fruit. Saetae and Suntornsuk stated that phorbol esters were found to be responsible for fungal growth inhibition in the crude extract of Jatropha curcas seed cake.

Antimicrobial activities observed in this study might be due to the presence of flavonoid compounds. Extracts of various medicinal plants containing phenolic and flavonoids have been previously reported to possess antimicrobial activity [19,20]. Vaquero et al. [21] investigated the properties of gallic, caffeic, vanillic acid, rutin, and quercetin of different wine against pathogenic microorganisms. Escherichia coli were the most sensitive bacterium and Flavobacterium sp. was resistant against all phenolic compounds tested. The flavonoid analyses (Table 1) revealed the presence of kaempferol, myricetin, naringin, quercetin and rutin in $P$. macrocarpa fruit. The presence of these compounds might contribute to antimicrobial activity of $P$. macrocarpa fruit since Cushnie and Lamb [11] reported that kaempferol, myricetin, naringin, quercetin and rutin have antimicrobial activity against human pathogenic microorganisms with some mechanisms of action such as inhibition of nucleic acid synthesis, cytoplasmic membrane function and energy metabolisms. The antimicrobial activity of the extracts of $P$. macrocarpa fruit might be due to one of the mechanisms of action mentioned above. Antimicrobial activity from pericarp, mesocarp, and seed of P. macrocarpa fruit might be due to the presence of kaempferol, myricetin, naringin, quercetin and rutin. Teffo et al. [22] isolated four kaempferols from Dodonaea viscosa Jacq. var. angustifolia leaf extracts and applied them to some human phatogenic bacteria. The results showed that all isolated kaempferols 
could inhibit growth rate of Staphylococcus aureus, Enterococcus faecalis, E. coli and Pseudomonas aeruginosa. In addition, Demetzos et al. [23] investigated the antimicrobial activity of myricetin and its derivate and the results showed that they could inhibit Gram-positive bacteria compared to Gram-negative. Furthermore, $\mathrm{Li}, \mathrm{Xu}$ and Mandalari et al. [24,25] mentioned that quercetin and naringin have antimicrobial activity.

Table 2. Antimicrobial activity of extracts obtained from various parts of P. macrocarpa fruit.

\begin{tabular}{|c|c|c|c|c|c|}
\hline \multirow[b]{2}{*}{ Microorganisms } & \multicolumn{5}{|c|}{ Inhibition zone $(\mathrm{cm}) *$} \\
\hline & Pericarp & Mesocarp & Seed & $\begin{array}{c}\text { Kanamycin } \\
\text { (1 } \mu \text { g/disc) }\end{array}$ & $\begin{array}{l}\text { Amphotericin } \\
\text { B }(25 \mu \mathrm{g} / \text { well })\end{array}$ \\
\hline \multicolumn{6}{|c|}{ Gram-Positive Bacteria } \\
\hline B. cereus & 1.73 & 1.53 & 1.40 & 1.63 & - \\
\hline B. subtilis & 2.33 & 2.00 & 1.83 & 1.33 & - \\
\hline M. luteus & 1.57 & 1.47 & 1.37 & 1.35 & - \\
\hline S. aureus & 1.53 & 1.73 & 1.40 & 1.35 & - \\
\hline Average & 1.79 & 1.68 & 1.50 & 1.42 & - \\
\hline \multicolumn{6}{|c|}{ Gram-Negative Bacteria } \\
\hline E. aerogenes & 1.50 & 1.30 & 1.20 & 1.55 & - \\
\hline E. coli & 2.17 & 1.47 & 1.47 & 1.73 & - \\
\hline K. pnuomoniae & 1.23 & 1.10 & 0.97 & 1.5 & - \\
\hline P. aeruginosa & 1.40 & 1.17 & 0.93 & 1 & - \\
\hline Average & 1.56 & 1.26 & 1.14 & 1.45 & - \\
\hline \multicolumn{6}{|l|}{ Fungi } \\
\hline A. niger & 0 & 0 & 1.87 & - & 2.70 \\
\hline F. oxysporum & 0 & 0 & 0 & - & 1.80 \\
\hline G. lucidum & 0 & 0 & 0 & - & 0.40 \\
\hline \multirow[t]{2}{*}{ M. indicus } & 0 & 0 & 0 & - & 1.20 \\
\hline & 0 & 0 & 0.47 & - & $1.53 \pm 0.97$ \\
\hline
\end{tabular}

* Inhibition zone in diameter $(\mathrm{cm})$; 0: no inhibition; analyses were done in triplicate.

The results of the present study are quite encouraging as almost all of extracts exhibited antimicrobial activity against most of the pathogens. However, the antimicrobial activity varies widely, depending on the microorganism.

\section{Experimental Methods}

\subsection{Plant Materials}

The fruits of $P$. macorcarpa were obtained from Faculty of Mathematic and Natural Sciences, University of Riau, Riau province, Indonesia. The plant species was identified by the laboratory of Plant Taxonomy staff at Herbarium Bogoriense, Bogor, Indonesia. The voucher specimen (SA1611/2008) was deposited at Herbarium Bogoriense, Bogor, Indonesia. The fruits were washed and separated into pericarp, mesocarp and seed. Those parts were air-dried for 7 days and kept for further analyses. 


\subsection{Extraction}

The extractions of $P$. macrocarpa were carried out based on Crozier et al. [16] with some modification. Air-dried powders of each part of $P$. macrocarpa $(0.5 \mathrm{~g})$ were weighed and placed into a $100 \mathrm{~mL}$ conical flask. $40 \mathrm{~mL}$ of methanol was added, followed by $10 \mathrm{~mL}$ and $6 \mathrm{M} \mathrm{HCL}$ solution. The mixture was stirred using a magnetic stirrer. The mixture was placed in a sample flask $(250 \mathrm{~mL})$, attached to reflux for $2 \mathrm{~h}$ at $90{ }^{\circ} \mathrm{C}$, then the mixture was filtered using Whatman No.1 filter paper (Whatman, England), and taken to dryness by using a vacuumed Rotary Evaporator (Buchii, Switzerland) at $40{ }^{\circ} \mathrm{C}$.

\subsection{Determination of Flavonoid Compounds by HPLC}

The flavonoid compounds of different parts of $P$. macrocarpa fruit were quantitatively measured by a reversed-phase HPLC technique based on the method described by Crozier et al. [16]. Flavonoid compounds standards consisted of quercetin, rutin, myricetin, kaempferol, naringin, apigenin, and luteolin. an aliquot of sample extract was loaded on a high-performance liquid chromatography (HPLC) Agilent-1200 series instrument equipped with a UV-Vis photodiode array (DAD) detector, binary pump, vacuum degasser, auto sampler and analytical column (Nova-Pak ${ }^{\circledR} \mathrm{C} 1860 \AA 4 \mu \mathrm{m}$ $3.9 \times 150 \mathrm{~mm}$, Waters, NANPA, MA, USA). The mobile phase comprises deionized water and acetonitrile. The $\mathrm{pH}$ of water was adjusted to 2.5 with trifluoroacetic acid. The flavonoid compounds were detected at $365 \mathrm{~nm}$. The column was equilibrated by $100 \%$ solvent A (15\% acetonitrile) then the ratio of solvent B (35\% acetonitrile) was increased to $100 \%$ in $20 \mathrm{~min}$. This ratio was maintained for the rest of the analysis with a flow rate of $1 \mathrm{~mL} / \mathrm{min}$.

\subsection{Antimicrobial Activity}

\subsubsection{Bacteria and Fungi Cultures}

The Gram-negative and -positive bacteria (Bacillus cereus, Bacillus subtilis, Enterobacter aerogenes, E. coli, Klebsiella pneumonie, Micrococcus luteus, P. aeruginosa, and S. aureus), fungi (A. niger, Fusarium oxysporum, Ganoderma lucidum, and Mucor indicus) were all purchased from the Institute of Malaysian Research (IMR) and maintained in the Department of Microbiology, Faculty of Biotechnology and Biomolecular Sciences, Universiti Putra Malaysia.

\subsubsection{Bacterial Susceptibility Testing}

The antibacterial assay of $P$. macrocarpa fruit extracts was carried out by the disc diffusion method [26]. All the microorganisms mentioned above were incubated at $37^{\circ} \mathrm{C}$ for $24 \mathrm{~h}$ by inoculation into nutrient broth. The culture suspensions were prepared and adjusted to approximately $10^{5}$ c.f.u. of bacteria/mL. One hundred microliters of the inoculate were spread over plates containing sterile nutrient agar. Paper filter discs $(6 \mathrm{~mm})$ impregnated with $10 \mu \mathrm{L}(0.30 \mathrm{mg} / \mathrm{disc})$ of each extract were placed on the surface of the media. The plates were left for $30 \mathrm{~min}$ at room temperature to allow the diffusion of the extracts and incubated at $37{ }^{\circ} \mathrm{C}$ for $24 \mathrm{~h}$. Finally, the inhibition zone around the disc 
was measured. Kanamycin $(1 \mu \mathrm{g} /$ disc $)$ was also included in the test as a reference control to evaluate the susceptibility of tested strains. The experiments were run in triplicate.

\subsubsection{Fungi Susceptibility Testing}

The antfungal assays of Phaleria macrocarpa fruit extracts were carried out by the agar well diffusion assay [27]. Briefly, a suspension of the tested fungi was prepared $\left(10^{5} \mathrm{spore} / \mathrm{mL}\right)$, added $100 \mu \mathrm{L}$ into agar plate and dispensed uniformly in the surface of the agar plate. The small wells were cut in the agar plate using a cork borer $(6 \mathrm{~mm})$. A fixed volume of extracts $(0.3 \mathrm{mg} / \mathrm{well})$ and (25 $\mu \mathrm{g} /$ well) Amphotericin B (PAA Lab., Cölbe, Germany) were loaded in the wells. The plates were incubated at $29^{\circ} \mathrm{C}$ for $72 \mathrm{~h}$ and the diameter of the inhibition zone around each well was recorded.

\section{Conclusions}

This study showed that $P$. macrocarpa fruit contained kaempferol, myricetin, naringin, and rutin as flavonoids. Moreover pericarp, mesocarp, and seed extract were potent as antimicrobial agents. The presence of flavonoids could contribute to its antimicrobial activities. It is suggested that $P$. macrocarpa fruit could be considered as source of antimicrobial agent which might be applied in pharmaceutical and cosmetic products.

\section{Acknowledgements}

The author would like to thank the Faculty of Biotechnology and Biomolecular Sciences, Universiti Putra Malaysia for the laboratory facilities and Faculty of Mathematic and Natural Sciences, University of Riau for providing the samples.

\section{References}

1. Backer, C.; van den Brink, R. Flora of Java (Spermatophytes Only); Noordhoff: Groningen, The Netherlands, 1965; Volume II.

2. Steffan, B.; Watjen, W.; Michels, G.; Niering, P.; Wray, V.; Ebel, R.; Edrada, R.; Kahl, R.; Proksch, P. Polyphenols from plants used in traditional Indonesian medicine (Jamu): Uptake and antioxidative effects in rat H4IIE hepatoma cells. J. Pharm. Pharmacol. 2005, 57, 233-240.

3. Zhang, Y.; Xu, X.; Liu, H. Chemical constituents from Mahkota dewa. J. Asian Nat. Prod. Res. 2006, 8, 119-123.

4. Oshimi, S.; Zaima, K.; Matsuno, Y.; Hirasawa, Y.; Iizuka, T.; Studiawan, H.; Indrayanto, G.; Zaini, N.C.; Morita, H. Studies on the constituents from the fruits of Phaleria macrocarpa. J. Nat. Med. 2008, 62, 207-210.

5. Hakim, R.; Nawawi, A.; Adnyana, I.; Achmad, S.; Makmur, E.; Hakim, E.; Syah, Y.; Kitajima, M. Benzophenone glucoside from red fruit Phaleria macrocarpa and test the activity against DPPH and murine leukemia cells P-388. Bull. Soc. Nat. Prod. Chem. 2004, 4, 67-70.

6. Kusmaardiyani, S.; Nawawi, A.; Rahmi, K. Isolation of benzophenone from Phaleria macrocarpa (Scheff.) Boerl. (Thymelaeaceae) leaf. Acta Pharm. Indones. 2004, 29, 150-152. 
7. Ao, C.; Li, A.; Elzaawely, A.A.; Xuan, T.D.; Tawata, S. Evaluation of antioxidant and antibacterial activities of Ficus microcarpa L. fil. extract. Food Control 2008, 19, 940-948.

8. Cragg, G.; Newman, D.; Snader, K. Natural products in drug discovery and development. J. Nat. Prod. 1997, 60, 52-60.

9. Manian, R.; Anusuya, N.; Siddhuraju, P.; Manian, S. The antioxidant activity and free radical scavenging potential of two different solvent extracts of Camellia sinensis (L.) O. Kuntz, Ficus bengalensis L. and Ficus racemosa L. Food Chem. 2008, 107, 1000-1007.

10. Cowan, M. Plant products as antimicrobial agents. Clin. Microbiol. Rev. 1999, 12, 564.

11. Cushnie, T.P.T.; Lamb, A.J. Antimicrobial activity of flavonoids. Int. J. Antimicrob. Agents 2005, 26, 343-356.

12. Wang, H.; Helliwell, K. Determination of flavonols in green and black tea leaves and green tea infusions by high-performance liquid chromatography. Food Res. Int. 2001, 34, 223-227.

13. Hakkinen, S.; Karenlampi, S.; Heinonen, I.; Mykkanen, H.; Torronen, A. Content of the flavonols quercetin, myricetin, and kaempferol in 25 edible berries. J. Agr. Food. Chem. 1999, 47, 2274-2279.

14. De Lourdes Mata Bilbao, M.; Andrés-Lacueva, C.; Jáuregui, O.; Lamuela-Raventós, R.M. Determination of flavonoids in a Citrus fruit extract by LC-DAD and LC-MS. Food Chem. 2007, $101,1742-1747$.

15. Kumar, B.; Lakshman, K.; Jayaveera, K.; Krishna, N.; Manjunath, M.; Suresh, M. Estimation of rutin and quercetin in Amaranthus viridis Linn by HPLC. Asian J. Exp. Sci. 2009, 23, 51-54.

16. Crozier, A.; Jensen, E.; Lean, M.E.J.; McDonald, M.S. Quantitative analysis of flavonoids by reversed-phase high-performance liquid chromatography. J. Chromatogr. A 1997, 761, 315-321.

17. Othman, F. Chemical Constituents and Biological Activities of Flavonoids from Hydroponically Grown Pegaga (Centella asiatica, Linn. Urban) Extracts; Universiti Putra Malaysia: Serdang, Malaysia, 2003.

18. Borris, R.; Blaskó, G.; Cordell, G. Ethnopharmacologic and phytochemical studies of the Thymelaeaceae. J. Ethnopharmacol. 1988, 24, 41-91.

19. Ayaz, F.; HayIrlloglu-Ayaz, S.; Alpay-Karaoglu, S.; Gruz, J.; Valentová, K.; Ulrichová, J.; Strnad, M. Phenolic acid contents of kale (Brassica oleraceae L. var. acephala DC.) extracts and their antioxidant and antibacterial activities. Food Chem. 2008, 107, 19-25.

20. Rahman, M.; Moon, S. Antimicrobial phenolic derivatives from Dendranthema zawadskii var. latilobum kitamura (Asteraceae). Arch. Pharm. Res. 2007, 30, 1374-1379.

21. Vaquero, M.J.R.; Alberto, M.R.; de Nadra, M.C.M. Antibacterial effect of phenolic compounds from different wines. Food Control 2007, 18, 93-101.

22. Teffo, L.; Aderogba, M.; Eloff, J. Antibacterial and antioxidant activities of four kaempferol methyl ethers isolated from Dodonaea viscosa Jacq. var. angustifolia leaf extracts. S. Afr. J. Bot. 2010, 76, 25-29.

23. Demetzos, C.; Angelopoulou, D.; Kolocouris, A.; Daliani, I.; Mavromoustakos, T. Structure elucidation, conformational analysis and thermal effects on membrane bilayers of an antimicrobial myricetin ether derivative. J. Heterocycl. Chem. 2001, 38, 703-710.

24. Li, M.; Xu, Z. Quercetin in a lotus leaves extract may be responsible for antibacterial activity. Arch. Pharm. Res. 2008, 31, 640-644. 
25. Mandalari, G.; Bennett, R.; Bisignano, G.; Trombetta, D.; Saija, A.; Faulds, C.; Gasson, M.; Narbad, A. Antimicrobial activity of flavonoids extracted from bergamot (Citrus bergamia Risso) peel, a byproduct of the essential oil industry. J. Appl. Microbiol. 2007, 103, 2056-2064.

26. Boussaada, O.; Chriaa, J.; Nabli, R.; Ammar, S.; Saidana, D.; Mahjoub, M.; Chraeif, I.; Helal, A.; Mighri, Z. Antimicrobial and antioxidant activities of methanol extracts of Evax pygmaea (Asteraceae) growing wild in Tunisia. World J. Microb. Biot. 2008, 24, 1289-1296.

27. Quiroga, E.; Sampietro, A.; Vattuone, M. Screening antifungal activities of selected medicinal plants. J. Ethnopharmacol. 2001, 74, 89-96.

(C) 2011 by the authors; licensee MDPI, Basel, Switzerland. This article is an open access article distributed under the terms and conditions of the Creative Commons Attribution license (http://creativecommons.org/licenses/by/3.0/). 